\title{
Intravenous Pyogenic Granuloma of the Finger
}

\section{Dong Hee Kim, Do Hun Kim, Hyoung Min Kim, Ji Heon Lee, Byung Woo An}

Department of Orthopaedic Surgery,

Samsung Changwon Hospital,

Sungkyunkwan University School of Medicine,

Changwon, Korea
Intravenous pyogenic granuloma is a rare form of lobular capillary hemangioma and typically consists of an intraluminal polyp attached to the wall of a vein by a fibro-vascular stalk. It rarely occurs in the finger and its character is not enough to diagnosis clinically. Therefore, we report intravenous pyogenic granuloma which occurs in dorsal side of mid-phalanx with magnetic resonance imaging and pathological findings.

Keywords: Intravenous pyogenic granuloma, Hemangioma, Finger

Received: September, 28, 2013

Revised: October, 24, 2013

Accepted: October, 26, 2013

Correspondence to: Byung Woo An

Department of Orthopaedic Surgery,

Samsung Changwon Hospital,

Sungkyunkwan University School of Medicine, 158 Paryong-ro, Masanhoewon-gu, Changwon 630-723, Korea

TEL: +82-55-290-6030

FAX: +82-55-290-6888

E-mail: bwa0820@naver.com

This is an Open Access article distributed under the terms of the Creative Commons Attribution Non-Commercial License (http://creativecommons.org/ licenses/bync/3.0/) which permits unrestricted noncommercial use, distribution, and reproduction in any medium, provided the original work is properly cited.

\section{서론}

화농성 육아종(pyogenic granuloma)은 피부 및 점막에 서 발생하는 0.5-2.0 cm 정도 크기의 양성 혈관종으로 소엽 모세혈관종으로도 불린다. 구강에 호발하며, 구강의 위생과 도 관련이 있다고 보고되었다. 이 중 정맥 내 화농성 육아종 (intravenous pyogenic granuloma)은 아직 정확한 병리기 전이 밝혀지지 않았으나, 특징적으로 정맥 내에 모세혈관의 증식에 의해 형성된 소엽의 형태를 보인다. 주로 두경부, 상지 의 혈관에서 발생하며, 수부의 혈관에서 발생하는 경우는 매
우 드물다 ${ }^{2,3}$. 본 증례는 54 세 여자의 좌측 제4수지 배부에서 발생한 정맥 내 화농성 육아종의 예로 임상적 진단, 병리 소견 및 치험에 대하여 보고하는 바이다.

$$
\text { 증례 }
$$

54 세의 여자 환자로 내원 1년 전 우연히 발견된 좌측 4수지 중지골 배부에 발생된 종괴를 주소로 내원하였다. 좌측 4수지 의 외상이나 다른 특이 병력은 없었으며, 자궁 경부암으로 내 원 10 년 전 자궁절제술을 받은 과거력 있었다. 수술 전 혈액 
J Korean Soc Surg Hand Vol. 18, No. 4, December 2013

검사상 적혈구침강속도(erythrocyte sedimentation rate) 및 $\mathrm{C}$-반응 단백질(C-reactive protein)은 정상범위였으며, 중성구의 경한 감소 및 임파구의 경한 증가 이외의 다른 특이 소견은 없었다. 발견 당시 직경 $2 \mathrm{~mm}$ 정도의 작은 종괴로 통 증 및 압통을 동반하지 않은 상태였다. 내원 당시에는 경한 통 증 및 압통이 동반된 $1.5 \mathrm{~cm}$ 정도 크기의 종괴였다. 단순방사 선 사진에서는 특이 소견은 보이지 않았으며, 자기공명영상 (magnetic resonance imaging, MRI) 소견상 수지 정맥과 수 지 신전 건에 연결되어있는 경계가 뚜렷한 피하 조직층 종괴로 확인되었다. T1 강조영상에서 피부와 균질한 신호의 영상으로 보였으며, T2 강조영상에서 고신호 강도, 조영 증가 후 역시 고신호 강도를 보이며 수지 정맥과 연속성을 보였다(Fig. 1).

국소마취하 피부 절개 후 육안적으로 양측이 정맥과 연결된 $1.6 \times 0.6 \times 0.3 \mathrm{~cm}$ 크기의 회백색 종양이 관찰되었다. 육안으 로 보이는 경계보다 $2 \mathrm{~mm}$ 원위부 및 근위부에서 전기소작하 여 전 절제를 시행하였다(Fig. 2). 병리 소견상 종양은 영양 공급 혈관을 포함한 줄기로 정맥 혈관벽에 부착되었으며, 혈 관 내강으로 돌출되어 있는 용종 모양이었다. 고배율 영상에
서는 혈관 증식 소견 및 단일 형태의 과형성된 내피세포로 구 성된 종양 소견으로 정맥 내 화농성 육아종으로 진단되었다 (Fig. 3).

수술 후 특별한 문제 없이 치유되어 수술 후 2 주째 발사하였 으며 이후 3 개월 간 추시 검사에서 재발의 흔적이나 혈류 장애 및 기능적 이상 소견은 보이지 않았다.

\section{고찰}

정맥 내 화농성 육아종은 Cooper 등에 의해 1979년 처음 기술되었다. 이는 육안상 정맥 벽에 부착된 잘 싸여진 용종 형 태의 종괴로 목과 상지의 정맥에 주로 분포하며 여성에 비교 적 호발하는 것으로 알려져 있다. 주로 통증은 동반하지 않으 나 종괴 내 궤양이 생기는 경우 통증을 호소할 수 있다. 수지 에 발생하는 정맥 내 화농성 육아종은 매우 드물며 이전까지 보고된 5예의 수부에 발생한 정맥 내 화농성 육아종의 경우 손 바닥부에서 발생한 경우가 많았다. 50\%에서 경한 통증과 압 통을 호소했으며 피부색깔의 변화를 동반하기도 하였다 ${ }^{4}$.
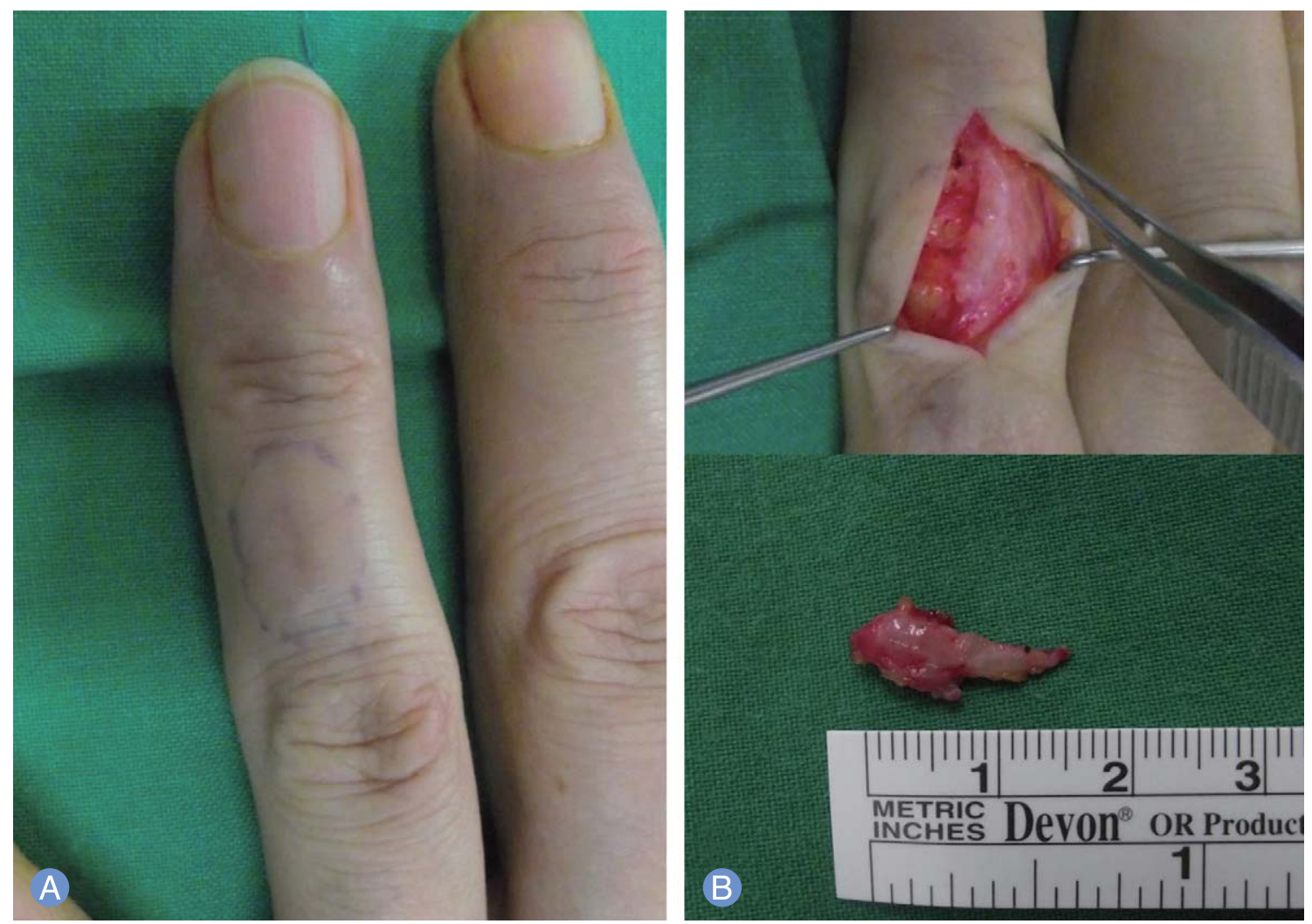

Fig. 1. (A) Preoperative photogragh shows $1.5 \times 0.5 \mathrm{~cm}$ palpable mass on the midphalanx level dorsal side of the fourth finger, left hand. (B) Intraoperative photogragh shows $1.6 \times 0.6 \mathrm{~cm}$ sized well-lobulated pale mass like region in the vessel of mid phalanx dorsal side. 

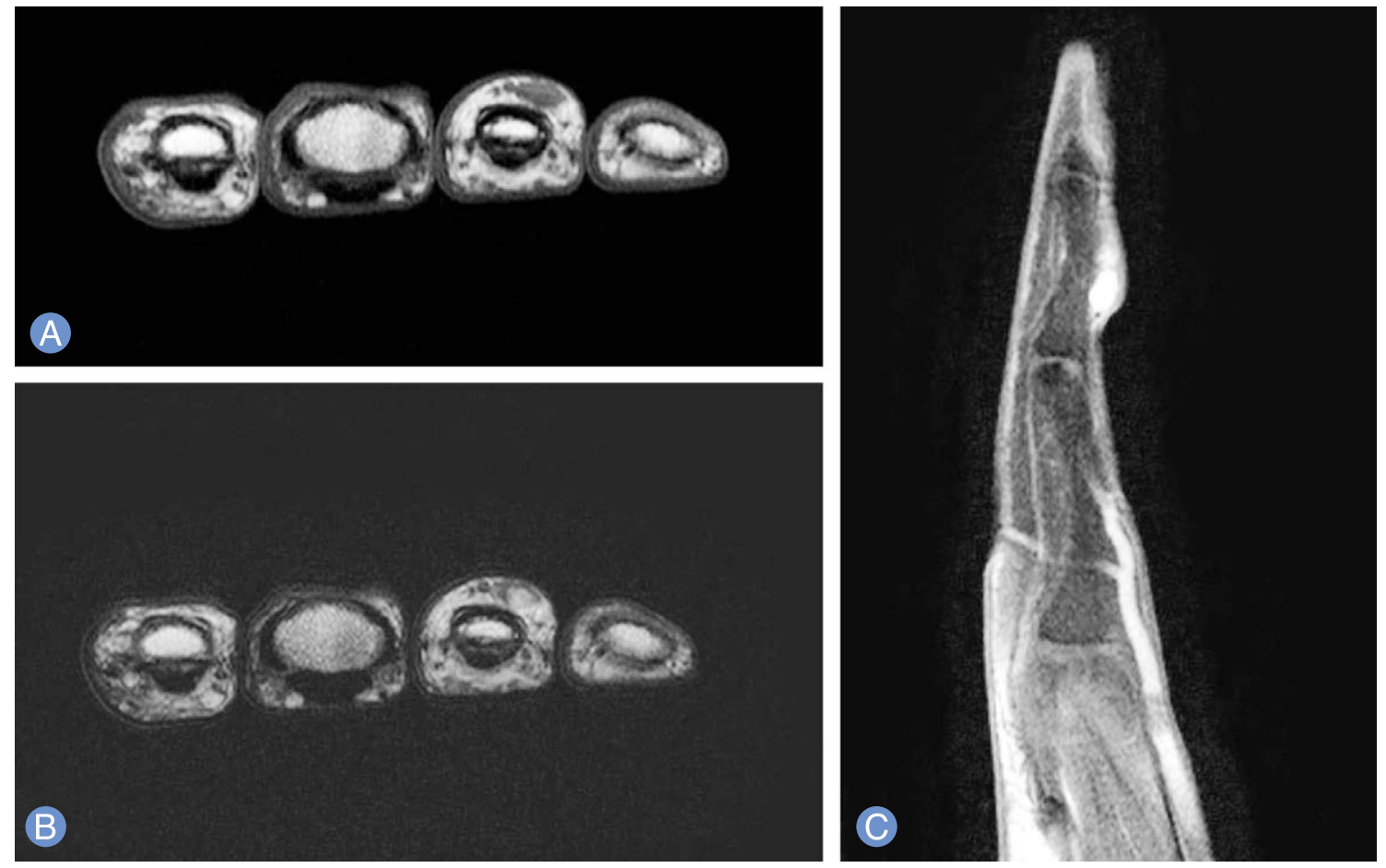

(B)

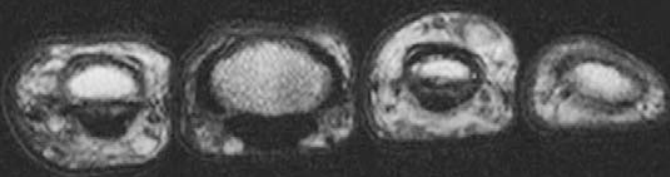

Fig. 2. Magnetic resonance imaging. (A) Axial view T1-weighted image shows that the signal of the lesion is equivalent to that of adjacent skin. (B) Axial view T2-weighted image shows $1.2 \times 0.4 \times 0.7 \mathrm{~cm}$-sized well-defined lobulating wellenhancing nodule at the subcutaneous layer of the middle phalanx level. (C) Axial and sagittal view T1-weighted image obtained after intravenous injection of gadolinium shows homogeneous enhancement of lesion.
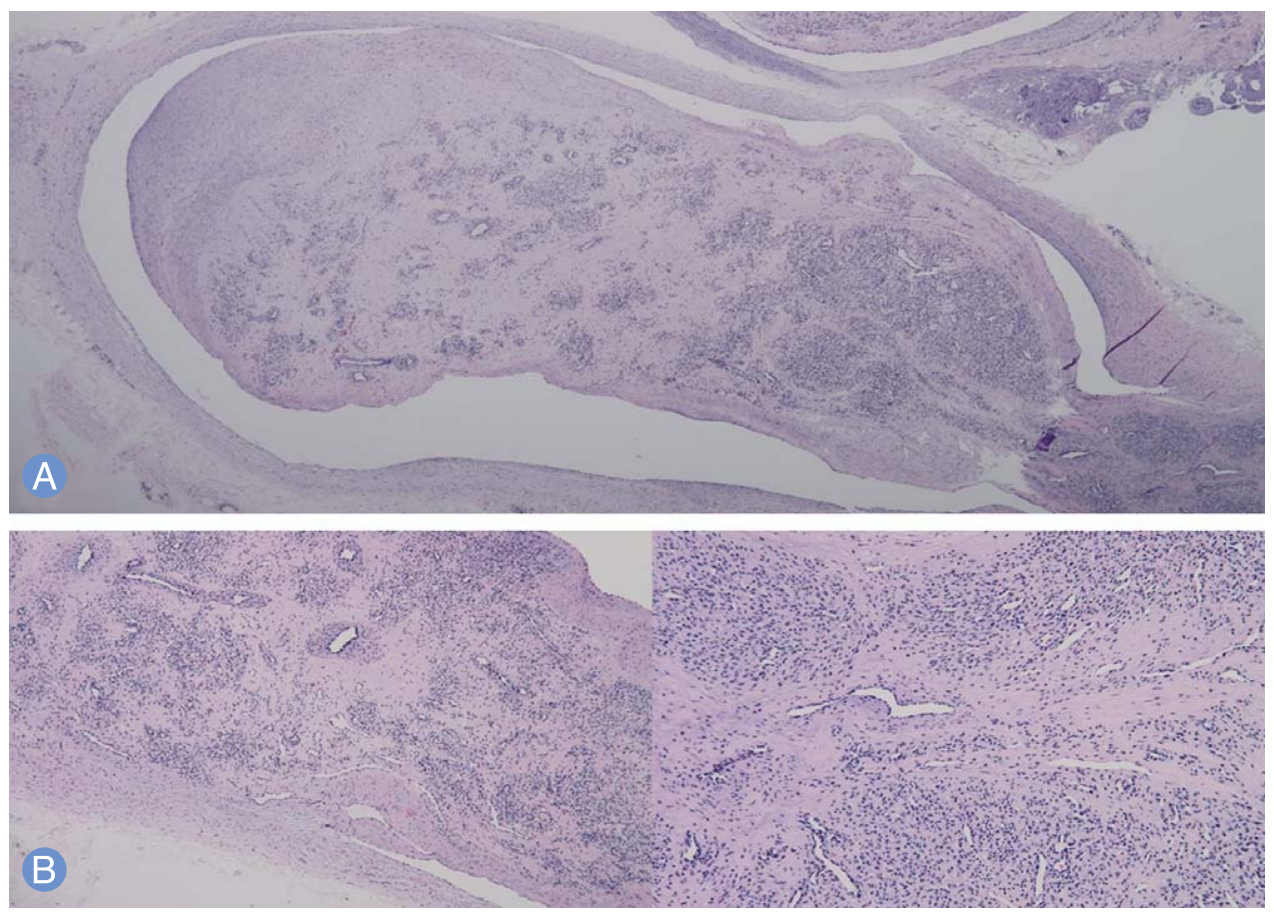

Fig. 3. Histological photograph (H\&E). (A) Subcutaneous nodule showing an intravenous polyp composed of lobules of capillaries separated by fibrous connective tissue attached to the wall of the vein by a fibrovascular stalk $(\times 40)$. (B) Higher magnification shows monotonous endothelial hyperplasia and capillary proliferation $(\times 200)$. 
J Korean Soc Surg Hand Vol. 18, No. 4, December 2013

정맥 내 화농성 육아종의 임상적 특징이 뚜렷하지 않아 수 술 전 감별 진단이 비교적 어려우며 대부분은 증상 없이 발견 하여 조직 검사에서 처음 진단되는 경우가 많다 ${ }^{2,4-7}$. 본 증례는 중년 여성의 경한 통증을 동반한 수지 배 측의 종괴로 임상적 으로는 결절종 혹은 건막 거대세포종을 의심하였다. 일부 저 자는 초음파 검사상 주변 피하 지방층보다 상대적 저에코 음 영 및 비균질성의 정맥 내 병변을 보여 진단에 도움이 되었다 고 하였다. $\mathrm{MRI}$ 상에서는 $\mathrm{T} 1$ 강조영상에서 피부 혹은 주변 근 육과 같은 신호영상으로 보이며 T2 강조영상 및 조영 증강 후 영상에서는 피부보다 고신호 영상으로 보인다고 보고되고 있 다, ${ }^{37}$. Ghekiere 등 3 은 조영 증강 시에 비균질성의 조영 증강 소견을 보이며 저강도 신호의 경계를 보여 전체적으로 혈관 내 병변 형태를 보인다고 하였으나 Kamishima 등은 종양 크 기가 작아 혈관성 병변임을 구분하기는 어렵다고 하였다. 본 증례의 경우 앞서 기술한 소견과 일치하며 T2 조영 증강 영상 에서 고신호 강도를 보였으며 주변의 저신호 강도의 경계를 구분하기는 어려웠고 수지 정맥과의 연결성을 통해 혈관성 종 양을 의심할 수 있었다.

정맥 내 화농성 육아종의 특징적인 병리학적인 소견은 대부 분 주머니 내에 싸여있는 여러 개의 결절 혹은 단결절로 이루 어져 있다는 것이다. 그 외에도 정맥 내 종양은 다수의 다양한 크기의 모세혈관이 종양 내 포함되어 소엽 형태를 이루고 있 으며 모세혈관 사이에는 섬유점액 기질로 이는 방추형세포와 콜라겐성 기질로 구성되어 있다. 고배율에서는 모세혈관이 평 편한 두꺼운 내피세포로 구성되어있으며 혈관 주위 세포의 불 연속층으로 둘러싸여있다2,6.

정맥 내 화농성 육아종은 정맥 내 유두모양 내막증식증 및 혈관 내 비정형 혈관증식증 등과 감별해야 한다. 정맥 내 유두 모양 내막증식증은 기질화 과정에서 특징적으로 여러 단계의 섬유소 혈전이 함유되어 있는 것이 특징적이며 ${ }^{8}$ 혈관 내 비정 형 혈관증식증은 혈관벽 밖으로 확장하며 세포를 더 많이 포 함하여 조직구 세포 및 내막 세포가 존재하는 것이 가장 큰 감 별점이 된다. 수지에 발생하는 정맥 내 화농성 육아종은 크기 가 작아 $\mathrm{MRI}$ 상 혈관성 종양을 구분하기 어려우므로 영상의학 적으로는 T2 및 조영 증강 시 고신호 강도로 보이는 사구체종
양과도 감별이 필요하다.

정맥 내 화농성 육아종의 치료는 기본적으로 침범된 정맥을 포함한 완전 국소절제를 권장하고 있으며, 수술 후 예후는 좋 으며 재발이 적은 것으로 알려져 있다 ${ }^{2,5}$. 본 예에서도 전 절제 술을 시행하였으며 추가적인 절제는 실시하지 않았다.

정맥 내 화농성 육아종은 드물게 발생하는 양성 혈관종으로 임상적 감별 진단이 어려워 조직학적 확인이 필요한 종양이 다. 수지에 발생하는 경우는 매우 드물며 완전 절제 후 예후는 좋은 편이다. 저자들은 수지 정맥 내 발생한 정맥 내 화농성 육아종의 1 예를 경험하여 보고하는 바이다.

\section{REFERENCES}

1. Leyden JJ, Master GH. Oral cavity pyogenic granuloma. Arch Dermatol. 1973;108:226-8.

2. Cooper PH, McAllister HA, Helwig EB. Intravenous pyogenic granuloma: a study of 18 cases. Am J Surg Pathol. 1979;3:221-8.

3. Ghekiere O, Galant C, Vande Berg B. Intravenous pyogenic granuloma or intravenous lobular capillary hemangioma. Skeletal Radiol. 2005;34:343-6.

4. Joethy J, Al Jajeh I, Tay SC. Intravenous pyogenic granuloma of the hand: a case report. Hand Surg. 2011;16:87-9.

5. DiFazio F, Mogan J. Intravenous pyogenic granuloma of the hand. J Hand Surg Am. 1989;14:310-2.

6. Qian LH, Hui YZ. Intravenous pyogenic granuloma: immunohistochemical consideration: a case report. Vasc Surg. 2001;35:315-9.

7. Kamishima T, Hasegawa A, Kubota KC, et al. Intravenous pyogenic granuloma of the finger. Jpn J Radiol. 2009;27:328-32.

8. Clearkin KP, Enzinger FM. Intravascular papillary endothelial hyperplasia. Arch Pathol Lab Med. 1976;100:441-4.

9. Rosai J, Akerman LR. Intravenous atypical vascular proliferation: a cutaneous lesion simulating a malignant blood vessel tumor. Arch Dermatol. 1974;109:714-7. 


\section{수지 내 발생한 정맥 내 화농성 육아종}

김동희 · 김도훈 · 김형민 · 이지헌 · 안병우

성균관대학교 삼성창원병원 정형외과학교실

정맥 내 화농성 육아종은 드문 형태의 소엽모세 혈관종으로 영양 공급 혈관을 포함한 줄기로 정맥 혈관벽에 부착되며 혈관 내강으로 돌출되어 있는 용종 모양을 보인다. 수지에 발생하는 경우는 매우 드물며 임상적 감별진단이 어려워 조 직학적 확인이 필요한 종양이다. 저자들은 중수지 배부에 발생한 정맥 내 화농성 육아종을 경험하여 자기공명영상 및 조직학적 소견 등을 포함한 진단 및 치료에 대한 정보를 주고자 이 증례를 보고하는 바이다.

색인단어: 정맥 내 화농성 육아종, 혈관종, 수지

접수일 2013년 9월 28일 수정일 2013년 10월 24일

게재확정일 2013년 10월 26일

교신저자 안병우

경상남도 창원시 마산회원구 팔용로 158

성균관대학교 삼성창원병원 정형외과학교실

TEL 055-290-6030, FAX 055-290-6888

E-mail bwa0820@naver.com 